\title{
The Annual of the British School at Athens
}

http://journals.cambridge.org/ATH

Additional services for The Annual of the British

School at Athens:

Email alerts: $\underline{\text { Click here }}$

Subscriptions: $\underline{\text { Click here }}$

Commercial reprints: $\underline{\text { Click here }}$

Terms of use : $\underline{\text { Click here }}$

\section{II.-Geraki: Historical Note}

\author{
H. J. W. Tillyard and Alan J. B. Wace
}

The Annual of the British School at Athens / Volume 11 / November 1905, pp 112 - 123

DOI: 10.1017/S0068245400002483, Published online: 18 October 2013

Link to this article: http://journals.cambridge.org/abstract_S0068245400002483

How to cite this article:

H. J. W. Tillyard and Alan J. B. Wace (1905). II.-Geraki: Historical Note. The Annual of the British School at Athens, 11, pp 112-123 doi:10.1017/S0068245400002483

Request Permissions : $\underline{\text { Click here }}$ 
Antigonus became master of Sparta. ${ }^{1}$ The reforms of Cleomenes were overthrown, ${ }^{2}$ and the old constitution brought back, though perhaps the kingship ${ }^{3}$ was abolished: and Sparta was forced to join the Achaean League. ${ }^{4}$ The change was welcome to the oligarchic party, which had chafed under the rule of Cleomenes. It was by this mild policy of conciliation that Antigonus won the goodwill of the Laconians and so gained such honours as our inscription records.

Antigonus was soon recalled to Macedonia by an inroad of the Dardanians. He met and routed them, but died soon after his victory.

His acts at Sparta did not long outlast his death. Early in 219 the Aetolian party in the city slew the Ephors; Sparta joined the Aetolian league and declared war on the Achaeans.

The generous dealing of Antigonus made an immediate and lasting impression in Southern Greece, as the following passage in Polyb. v. 9 clearly shows : after mentioning the reforms already detailed in Book ii.

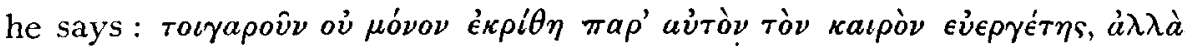

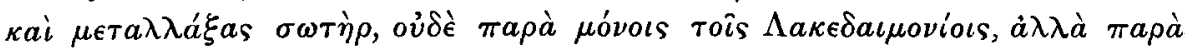

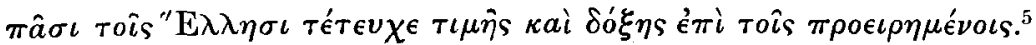

This passage explains our inscription, and states that Antigonus was called $\epsilon \dot{v} \epsilon \rho \epsilon^{\prime} \tau \eta$ in his life-time, but Soter after his death. Our inscription is therefore later than 22I. Again, it is very unlikely that a statue would be set up to Antigonus in Laconia, when his settlement of Laconian affairs had been violently overthrown. Hence we may place our inscription before 219 , when Sparta joined the Aetolian League. ${ }^{6}$

H. J. W. Tillyard.

\section{HISTORICAL NOTE.}

In connection with the inscription from Geraki (No. II) published above, and the parallel inscription from Mantinea, it seems worth while to

1 Plut. Arat. c. 46 init. ; Cleom. cc. 28-30; Polyb. iv. 34 ff. ; cf. Droysen, Gesch. d. Hellen. iii. 2, pp. I47-155; Beloch, Gr. Gesch. iii. I, p. 743 ; Niese, Gesch. d. gr. u. mak. Staaten ii. pp. 332 ff.

2 Polyb. ii. $70 \$$ I. $\quad 3$ So Beloch, l.c., supposes.

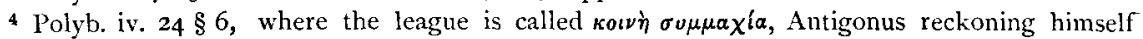
one of the $\sigma \dot{v} \mu \mu a x o$.

5 Compare also Polybius iv. $34-36$, and especially ix. $36 \$ 3$, where in Lyciscus' speech to the Spartans on behalf of Macedonia (B.C. IO7) the following words occur :-('Avtígovos) $\epsilon_{\kappa} \beta a \lambda \dot{\omega} \nu$

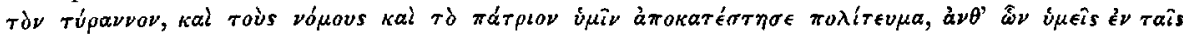

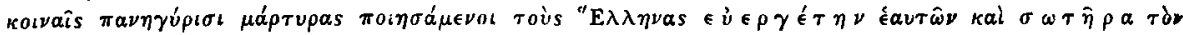

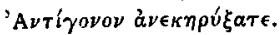

${ }^{6}$ Cf. Niese, op. cit. ii. pp. $425 \mathrm{ff}$ 
discuss two obscure points. (I) The history of Demetrius the Fair, the father of Antigonus Doson. (2) The worship of the earlier Diadochi. The following genealogical tables are necessary to explain the complicated family relationships.

\section{I.-Ptolemaic House.}

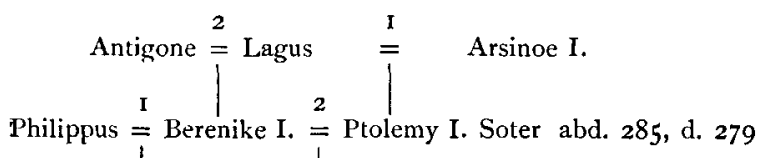

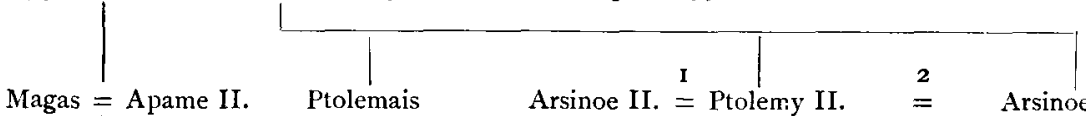

Magas = Apame II

Arsinoe II. = Ptolemy II. $=$

= Demetrius I. dau. of Lysimachus

widow of

Lysimachus

Berenike II.

Demetrius, o Ka入ós

Ptolemy III.

Berenike III.

$=$ Antiochus II.

\section{II.-Seleucid and Antigonid Houses.}

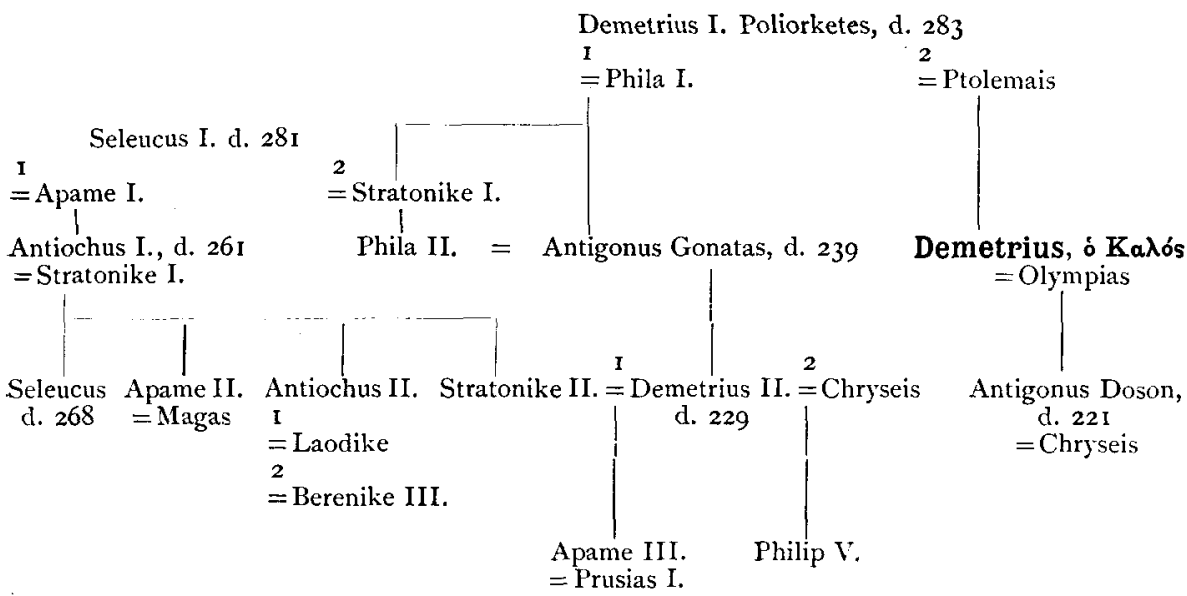

§ I.-The History of Demetrius the Fair.

Demetrius was the son of Demetrius Poliorketes by Ptolemais daughter of Ptolemy I. The marriage of his parents resulted from the peace made about 296-5 between Demetrius and Ptolemy. Demetrius Poliorketes was at that time master of Cilicia and had a strong fleet, and 
he and Ptolemy had been carrying on war round Cyprus and the adjoining coasts ${ }^{1}$ for about two years. We may assume then that Demetrius the Fair was born about 295-4. He is mentioned by Justinus and Eusebius, but as both these authors confuse him with his nephew Demetrius II., there are various difficulties concerning his history. ${ }^{2}$ The principal ascages referring to him are here quoted for convenience of reference.

Justinus xxvi. 2, 3 :-

Antigonus . . . bellum Atheniensibus infert. In quo cum occupatus esset, interim Alexander, rex Epiri ... fines Macedoniae depopulatur. Adversus quem cum reversus a Graecia Antigonus esset, transitione militum destitutus regnum Macedoniae cum exercitu amittit. Huius filius Demetrius puer admodum, absente patre reparato exercitu non solum amissam Macedoniam recipit, verum etiam Epiri regno Alexandrum spoliat. . . . Per idem tempus rex Cyrenarum Magas decedit, qui ante infirmitatem Berenicen, unicam filiam, ad finienda cum Ptolemeo fratre certamina filio eius desponderat. Sed post mortem regis mater virginis Arsinoe ${ }^{3}$ ut invita se contractum matrimonium solveretur, misit qui ad nuptias virginis regnumque Cyrenarum Demetrium, fratrem regis Antigoni a Macedonia arcesserent, qui et ipse ex filia Ptolemei procreatus erat. Sed nec Demetrius moram fecit. Itaque cum secundante vento celeriter Cyrenas advolasset, fiducia pulchritudinis, qua nimis placere socrui coeperat, statim a principio superbus regiae familiae militibusque impotens. erat studiumque placendi a virgine in matrem contulerat. Quae res suspecta primo virgini, dein popularibus militibusque invisa fuit. Itaque versis omnium animis in Ptolemei filium insidiae Demetrio comparantur, cui cum in lectum socrus concessisset, percussores inmittuntur. Sed Arsinoe audita voce filiae ad fores stantis et praecipientis ut matri parceretur, adulterum paulisper corpore suo protexit. Quo interfecto Berenice et stupra matris salva pietate ulta est et in matrimonio sortiendo indicium patris secuta.

Eusebius i. 237 :-

Cui filius ejus Demetrius successit, qui etiam universam Libyam cepit et Cyrenem obtinuit; quaeque erant patris cuncta recuperans ei in monarchicam potestatem redegit, dominatusque est annis $\mathrm{x}$.

${ }^{1}$ Droysen, Gesch. d. Hellen. ii. ${ }^{2}$ p. 243 ; Niese, Gesch. d. gr. u. mak. Staaten, i. p. 355.

2 v. Beloch, op. cit. iii. 2, pp. I33 seqq. ; cf. von Prott, Rhein. Museum, liii. p. 470.

3 Justinus with his usual carelessness writes Arsinoe instead of A pame. 
Idem, i. 243 :-

Obiit etiam Demetrius cognomento Pulcher anno c. tricesimae Olympiadis secundo. Regnum deinceps ad Philippum pervenit. . . .

Anon. apud Scal., p. $62:-$

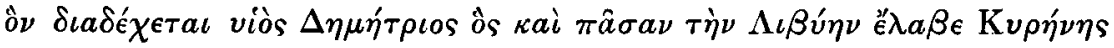

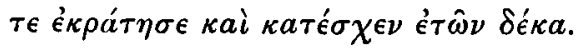

Trogus, Prol. xxvi. :-

Ut in Syria rex Antiochus cognomine Soter . . . decesserit. Ut in Asia filius Ptolemaei regis socio Timarcho desciverit a patre. Ut frater Antigoni Demetrius occupato Cyrenis regno interiit. Ut mortuo rege Antiocho filius eius Seleucus Callinicus regnum acceperit.

There is an obvious confusion in Eusebius between the two Demetrii. We may take the Cyrene episode as belonging entirely to Demetrius the Fair : the defeat of Alexander II. of Epirus might have been an exploit of either. The date given by Eusebius for the death of Demetrius the Fair is clearly wrong. There is great confusion here, since he plainly states that Philip V. succeeded Demetrius the Fair as king in Macedonia in 258. A few lines below he gives another wrong date for the death of Philip. Therefore we must disregard this passage of Eusebius. A new chronology must be attempted. Now by Trogus the death of Demetrius is placed between the revolt of Ephesus under Ptolemy and the death of Antiochus II. in 246. The date of Ptolemy's revolt is not exactly known. Ephesus is conjectured to have been taken by Ptolemy II. from Antiochus II. about 258, and Ptolemy was then installed as governor. ${ }^{1}$ His revolt must have taken place a little later than this. On the other hand Justinus' words Ptolemei flium in speaking of Ptolemy III. suggest that his father was still alive. Ptolemy II. died in 247: therefore we may set the death of Demetrius between 256 and 247. Demetrius cannot have been killed very long before the death of Ptolemy II, for Berenike was still a young wife ${ }^{2}$ when her husband, Ptolemy III. Euergetes set out on his great expedition in 246 to avenge his sister's death.

More evidence can be obtained by determining the date of the death of Magas. This is entirely unknown. Hitherto it has been assumed that

1 Trogus, loc. cit.; Athenaeus, xiii. 563 b; Beloch, op. cil. iii. 2, p. I3I.

${ }^{2}$ Catullus, Ixvi. I I. 
since Demetrius according to Eusebius was killed in 258, Magas died in the same year, and that the invitation of Demetrius to Cyrene, his betrothal to Berenike, his intrigue with Apame, and his death all took place in that same year. Magas reigned fifty years, ${ }^{1}$ but we do not know when his reign began. Ptolemy I. subdued Cyrene through Ophellas in $323 .{ }^{2}$ In 312 there was a revolt, and Agis was sent to relieve the Ptolemaic garrison (under Ophellas?) besieged in the citadel, and crushed the rebels. ${ }^{3}$ Ptolemy himself may have gone to Cyrene at this time. ${ }^{4}$ In 309 Ophellas, by then master of Cyrene and independent, was invited by Agathocles to aid in attacking Carthage in Africa. Ophellas in 308, having accepted this invitation, marched to join Agathocles, but was slain through the latter's treachery. ${ }^{5}$ Pausanias, ${ }^{6}$ having mentioned the death of Antigonus (3OI) and Ptolemy's occupation of Coele Syria, goes on to tell us that Cyrene had revolted, but was taken after four years by Magas. Is Pausanias to be taken seriously and has he mentioned these occurrences in chronological order? If Pausanias' order is chronological, Magas must have occupied Cyrene in 301 , and died in $25 \mathrm{I}$. But perhaps Pausanias is not to be relied on as being precise in this matter. In the same chapter he speaks as though Demetrius Poliorketes' victory at Salamis was won the year after his defeat at Gaza, whereas there was an interval of six years between them. ${ }^{7}$ Therefore we may conclude that the revolt Magas put down was that due to Ophellas. Ophellas, who was apparently being besieged in the citadel of Cyrene in 312 , can hardly have been powerful enough to declare himself independent before the end of 31. We do not know of any conquest or revolt of Cyrene between Ophellas' departure to join Agathocles and Antigonus' death at Ipsus. So if we may decide that Ophellas became independent in $3 \mathrm{II}-3 \mathrm{IO}$, Magas would have reconquered Cyrene for Ptolemy in 307-306. Thus Magas' ${ }^{8}$ death would fall in 257-256. Further help can be obtained if we could date the attack of Alexander II. of Epirus mentioned by Justinus. This occurred apparently while Antigonus Gonatas was besieging Athens during the Chremonidean war. Since Athens was taken about $263,^{9}$ Alexander's inroad must have taken place before. But it cannot have occurred very long before the fall of Athens, if Justinus'

1 Athenaeus, xii. 550.

4 Pausanias, i. 6. 5.

- ${ }^{2}$ Diodorus, xviii. 21.

5 Justinus, xxii. 7 .

8 Magas' revolt probably took place after the death of Ptolemy I. ; Pansanias, i. 7. 1 .

9 Beloch, Gr. Geschichte, iii. ${ }^{2}$ pp. 424 seqq.

3 Idem, xix. 79

6 i. 6. $8 . \quad 7$ i. 6.6. 
phrase per idem tempus . . Magas decedit is to be taken literally, since we have seen that Magas' death at the earliest would fall in 257. Assuming Alexander's inroad to have occurred about 265-264, if Magas died in 257-256, the use of per idem tempus ${ }^{1}$ might be justifiable.

Now Eusebius says dominatusque est annis $x$. It is just possible that the confusion between Demetrius II. and Demetrius the Fair may have arisen partly from the similarity of name, partly from the fact that both reigned ten years. If Demetrius reigned in Cyrene from 256-247, he could be said to have reigned ten years. That Demetrius was $\beta a \sigma \iota \lambda \epsilon v_{s}$ in Cyrene is evident from the Mantinea inscription. ${ }^{2}$ The Antigonus there referred to is clearly shewn by the Geráki inscription to be Antigonus Doson, therefore $\beta a \sigma \iota \lambda \lambda^{\prime} \omega \varsigma \Delta \eta \mu \eta \tau \rho i o v$ can only mean Demetrius the Fair.

The history of Demetrius the Fair is then briefly thus. $\mathrm{He}$ was born not earlier than 295, and probably accompanied his father to Macedonia, and after his father's expulsion lived with his half-brother Antigonus Gonatas. About 265, when the latter was temporarily driven from his kingdom by Alexander II. of Epirus, Demetrius coming to the rescue not only routed him, but carried the war into the enemy's country and drove Alexander in his turn into exile. So when Magas died not long after (257-256), he was a very suitable person for Apame to summon to marry her daughter and protect Cyrene from Egypt. Demetrius was not only first cousin to Berenike, but also a tried soldier. Demetrius accepted the invitation to Cyrene, and in due course became $\beta a \sigma \imath \lambda \epsilon u$ s and was probably betrothed to Berenike. Berenike at her father's death (257-256) can hardly have been more than 17 at most, since her mother Apame was. not married till 275-274, and cannot have been over 16 at the time of her marriage. ${ }^{3}$ Therefore the intrigue that followed between Demetrius and Apame was perhaps natural if we consider that they were both about the same age, that he would naturally prefer the woman to the immature girl, and that Demetrius was of considerable personal beauty.4 But his tragic end narrated so dramatically by Justinus was fully deserved.

The duration of his reign in Cyrene (256-247) overlaps to some extent the period of the second Syrian war. ${ }^{5}$ This, when we consider the

${ }^{1}$ Cf. Beloch, op. cit. pp. 426 seqq.

2 Eumenes of Pergamum does not take the title nor does he give it to his father by adoption, Philetaerus, in two Pergamene inscriptions, Dittenberger, O.G.I. 266, 267.

${ }^{3}$ Cf. J.H.S. I905, p. 104.

${ }^{5}$ Cf. Niese, op. cit. p. I34.

4 Cf. his nickname Kàós ; $v$. Diogenes Laert. iv. $4 \mathrm{I}$. 
close connection of Magas with the first Syrian war, is very suggestive. ${ }^{1}$ Justinus tells us that Magas had betrothed Berenike to the son of Ptolemy II. This was perhaps one of the terms of the treaty concluding the first Syrian war. Antiochus I. died in 26I, and Magas a few years later. The two kings who had concluded the peace were both dead, Egypt had been weakened by the Chremonidean war, and yet Cyrene against its will was to be reunited to Egypt through the marriage of Berenike and Ptolemy II.'s son. Further the Antigonid dynasty was now friendly and closely related to the Seleucid, and hostile to the Ptolemaic. Consequently Demetrius, as a prince who would support the AntigonidSeleucid alliance against Egypt and as son of a Ptolemaic princess, was summoned to Cyrene at the instance of Apame, who was true to the interests of her relations, and perhaps by the decision of the Cyrenaeans. Probably to this period belongs the marriage of Stratonike, sister of Antiochus II., to Demetrius, the young son of Antigonus Gonatas, to cement the alliance. ${ }^{2}$ The combination against Ptolemy was serious, but he seems to have caused his enemies some loss. Early in the war he seized Ephesus, and though he soon lost it again he seems to have captured many towns on the Asia Minor littoral from Antiochus. In Greece, too, he supported the Achaeans against Antigonus, and it was probably through Ptolemaic intrigues that Alexander, ${ }^{3}$ son of Kraterus, governor of Corinth and Euboea, revolted against Antigonus. Demetrius the Fair seems to have been successful and consolidated his power in Cyrene and Libya. The war lasted till about 250.4 Then Antiochus, weakened by the revolt of Diodotus, was forced to make peace: he put away his wife Laodike and married Berenike, Ptolemy's daughter, receiving Ephesus as her dowry. This seems to indicate a rapprochement between Antiochus and Ptolemy, and would account for the former's non-interference in Cyrene after Demetrius' death in 247 , even were the revolt of Parthia not sufficient explanation. But at Demetrius' death Cyrene, ${ }^{5}$ to judge by Justinus' words versis omnium

1 v. Lehmann, Beitr. 2. alt. Geschichte, iii. pp. 496 seqq.

${ }^{2}$ Beloch, op. cit. p. 92, suggests that the marriage of Phila with Antigonus Gonatas having taken place at the close of the war between him and Antiochus I., Demetrius was born about 276 . Consequently he would have been about i 8 in $25^{8}$.

${ }^{3}$ Trogus, Prol. xxvi. ${ }^{4}$ Niese, op cit. p. 139.

5 It is worth remarking the frequency of the revolts of Cyrene against I'tolemaic rule. Besides those mentioned we know of two others (Polybius, x. 22. 2; Plutarch, Philopoemen 1, Aratus 5 ; and Polyaenus, viii. 70); further during the reign of Philometor it was independent under Euergetes II., and later from I I 7-96 it was ruled by Ptolemy Apion quite independent of Egypt. 
animis in Ptolemei flium, seems to have voluntarily united itself with Egypt again.

We may then assume that the second Syrian war began in 258 B. C. between Antigonus and Antiochus II. on one side, against Ptolemy II. on the other, Magas remaining neutral. The principal events of the war would then seem to have been as follows :-258 Capture of Ephesus by Ptolemy ; 257-256 Death of Magas, and invitation of Demetrius to Cyrene; 256 Victory of Antigonus off Cos over the Ptolemaic fleet; ${ }^{1} 25$ I Revolt of Alexander, governor of Corinth ${ }^{2}$; 250 Revolt of Diodotus of Bactria, and conclusion of peace.

Thus at the conclusion of the war Demetrius was still in possession of Cyrene. It is doubtful if he ever really married Berenike. Justinus uses the word virgo to describe her, so it is most probable she was never married to Demetrius. There are two somewhat parallel cases. Cleopatra daughter of Antiochus III., though betrothed to the young Ptolemy V. ${ }^{3}$ by the treaty after the battle of Panion in 198 was not married to him till I93; also Alexander Balas ${ }^{4}$ did not marry Cleopatra daughter of Ptolemy Philometor till his attempt on the Seleucid throne had proved successful.

\section{\$2.-ThE WORShip OF THE EARLIER Diadochi.}

The two inscriptions help to confirm the conclusion arrived at by Kornemann ${ }^{5}$ that the earlier Diadochi were not deified till after their.death. The passage from Polybius quoted above says that Antigonus Doson

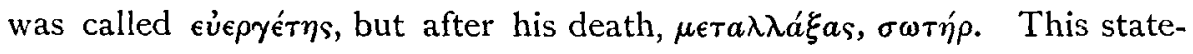
ment is confirmed by the inscriptions. Now this verb, with its corresponding noun $\mu \epsilon \tau a \lambda \lambda a \gamma \eta^{\prime}$ and the similar verb $\mu \epsilon \theta i \sigma \tau a \sigma \theta a \iota$ is specially used to describe the death of kings, as indicating their passing from earth to heaven. ${ }^{6}$ It is particularly noticeable that Antigonos Doson was not called $\sigma \omega \tau \eta \dot{p}$ till after death, till he had left the company of men for that of gods. It therefore seems at least probable that the official attribution of the title $\sigma \omega \tau \eta \dot{n} \rho$ implies deification. A brief examination of the inscriptions and literature will show the probability of this hypothesis as regards the third century.

1 Beloch, op. cit. iii. 2, p. 432.

3 Mahaffy, Emp. of Ptolemies, p. 306.

5 Beitriage z. alt. Geschichte, i. p. 67.
2 Ide'm, ibid. pp. 436 seqq.

4 Maccabees, i. 10, 5 I.

${ }^{6}$ v. Kornemann, op. cit. p. 61, I. 
I. Antigonid House.-Antigonus and Demetrius Poliorketes were hailed as $\sigma \omega \tau \hat{\eta} \rho \in \varsigma$ by the Athenians in $307 .^{1}$ At that time they had not even taken the title $\beta a \sigma \iota \lambda \epsilon v^{\prime}$; and they did not take the name $\sigma \omega \tau \eta \dot{p} \rho$ officially, but it was merely applied to them by a servile state. Demetrius Poliorketes was honoured at Sicyon as $\kappa \tau i \sigma \tau \eta{ }^{2},{ }^{2}$ and festivals and sacrifices were established for Antigonos Gonatas, ${ }^{3}$ and for Antigonos Doson ${ }^{4}$ during his lifetime.

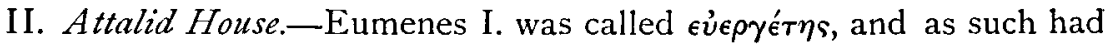
a festival and sacrifices. ${ }^{5}$ Three, perhaps four, inscriptions apply the title Soter to Attalus I : ${ }^{6}$ three of these are altars, the fourth is a statue base. These inscriptions may well date from after his death. In another inscription ${ }^{7}$ Attalus is called $\theta \epsilon$ és if the restoration is correct, but the inscription dates from after his death, since in it appears $\beta a \sigma i \lambda \iota \sigma \sigma a$

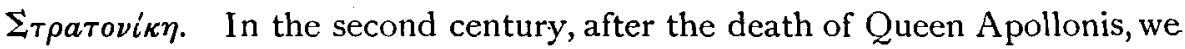
find Eumenes II. officially given the title Soter during his lifetime. ${ }^{8}$

III. Ptolemaic House.-The Rhodians honoured Ptolemy I. as a god according to Diodorus, ${ }^{9}$ and Pausanias ${ }^{10}$ is our only authority for the statement that they called him $\Sigma \omega \tau \eta \dot{p} \rho$. Otherwise the epigraphic evidence is all in favour of the view that he received the title when he was deified after

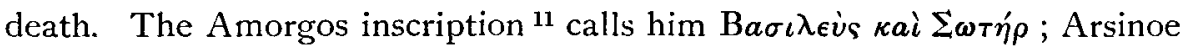
in the Halicarnassus inscription ${ }^{12}$ calls him $\Sigma \omega \tau \eta \rho ;$ and many other inscriptions dating from after his death give him the same title, most of them using the title almost as an equivalent to $\Theta \epsilon$ s. $^{13}$

In the case of Ptolemy II. there are no Greek inscriptions which give us any reason to suppose that he was deified during his lifetime. ${ }^{14}$ The revenue ${ }^{15}$ laws dating from the twenty-seventh year of his reign (258) long after the death of Arsinoe, ${ }^{16}$ his sister-wife whom he deified, do not give him

1 Diodorus, $\mathrm{xx} .46,2$.

$2 I d . \times x .102,3$.

3 B.C.H. 1882, p. 143, 1886, p. 1022.

4 Plutarch, Aratus, 45.

${ }_{5}^{5}$ Fränkel, Inschrift. v. Perg. I8 ; cf. Cardinali, Regno di Pergamo, pp. 139 seqq. esp. 156-1 58.

- Id. op. cit. 43, 45, 59 ; Dittenberger, O.G.I. 289.

7 Fränkel, op. cit. 171 .

${ }^{8}$ Dittenberger, O.G.I. 308 ; Apollonis' death falls between 166 and I 59. Eumenes is also called Soter in a Delphian inscription dating from soon after 167 , Id. op. cit. 305 .

9 xx. 100. 10 i. 8. $6 . \quad{ }^{11}$ Dittenberger, Syll. i. ${ }^{2} 202 . \quad{ }^{2}$ Id. O.G.I. I6.

13 Id. $0 . G .1$. 19, 22, 23, 25, 29 ; cf. Theocritus, xv.:47; evidence also from papyri, Konnemann, op. cit. p. 68, 2. The coins inscribed $\Pi$ TO $\wedge$ EMAIOY $\Sigma \Omega$ THPO $\Sigma$ were possibly not

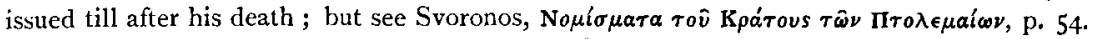

14 Dittenberger, O.G.I. 35, 39-47.

${ }_{15}$ Mahaffy, Revenue Laws, cols. 1, 24.

16 She died in his fifteenth year $271-270$. 
any divine title. However, Kornemann, ${ }^{1}$ following Von Prott ${ }^{2}$ who bases his argument on Wilckens's ${ }^{3}$ article on Arsinoe, states that the deification of the dead Arsinoe as $\Theta \epsilon a ̀$ $\phi i \lambda a ́ \delta \epsilon \lambda \phi o s$ resulted, through the influence of the Egyptian priesthood, in the deification of the living Ptolemy II. Arsinoe was in fact so deified during her lifetime, and later still during the lifetime of Ptolemy II. the cult of the $\Theta \epsilon \circ$ ' 'A $\delta \epsilon \lambda \phi o$ i was instituted. But it is remarkable that our knowledge of these cults at this period is derived from Egyptian ${ }^{4}$ and not from Greek sources.

It seems likely that the title $\Theta \in o i$ á $\delta \in \lambda \phi o i$ was not the only one applied to Ptolemy II. and his wife. An altar recently found at Alexandria ${ }^{5}$ bears the following inscription :-

\section{$B A \Sigma I \wedge E \Omega \Sigma \Pi T O \wedge E M A I O Y$ KAIAP $\Sigma I N O H \Sigma \phi I A A \triangle E \Lambda$ OY $\Theta E \Omega N \Sigma \Omega T H P \Omega N$}

Apparently on being deified they were worshipped as $\Theta \epsilon o i \Sigma \omega \tau \hat{\eta} \rho \epsilon \varsigma ;{ }^{6}$ the title $\Theta_{\epsilon o i} \dot{a} \delta \epsilon \lambda \phi o i$ must be later. Further, the coins bearing on one side heads of Ptolemy II. and Arsinoe, and on the other those of Ptolemy I. and Berenike, have the inscriptions $A \triangle E \wedge \phi \Omega N$ and $\Theta E \Omega N{ }^{7}$ It sounds from this as though the distinction in the words was between mortal and divine; had the difference between the two pairs as gods been intended to be emphasized, surely the inscriptions would have been $A \triangle E \wedge \phi \Omega N$ and $\Sigma \Omega T H P \Omega N$.

As regards Ptolemy III. and his wife Berenike, they we know were deified during their lifetime ${ }^{8}$ and so were the succeeding Ptolemaic kings. This custom, that the priesthood should deify the living king, is as Von Prott ${ }^{9}$ pointed out a compromise between Greek and Egyptian custom. Kornemann ${ }^{10}$ accepts this view, and especially emphasizes the Egyptian character of this idea of the divinity of the king.

1 Op. cit. pp. 70 seqq.

3 Pauly-Wissowa, Real-Encyclopiadie, Arsinoe, 26.

2 Rhein. Mus, liii, pp. 463 seqq.

$4 v$. the references given by Wilcken loc. cit. which, owing to the inaccessibility of the books, it has been impossible to verify.

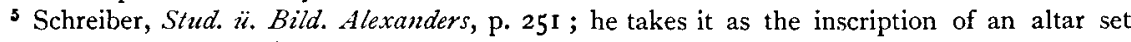
up by Ptolemy II. and Arsinoe to the $\Theta \in \circ i \Sigma \omega \tau \hat{\eta} \rho \in s ;$ the Greek will hardly bear this translation. The use of $\beta a \sigma \iota \lambda \epsilon \in$ s may imply that Ptolemy was still alive.

6 Ptolemy IV. is called Soter, Dittenberger, O.G.I. 89.

7 B.MI.Cat. Ptolemies, Pl. VII. $\quad{ }^{8}$ Dittenberger, O.G.I. 64.

9 Loc. cit. p. 466.

10 Op. cit. p. 75 . 
IV. Seleucid House.-An inscription of Ilion provides for the establishment of sacrifices and the erection of an altar to Seleucus I. with the

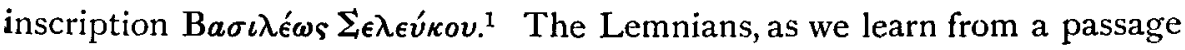
of Phylarchos quoted by Athenaeus, ${ }^{2}$ called Seleucus $\sigma \omega \tau \eta \dot{\rho}$; but Phylarchos especially condemns this as flattery. That festivals in his honour were established is known, ${ }^{3}$ but we know that he was not really deified

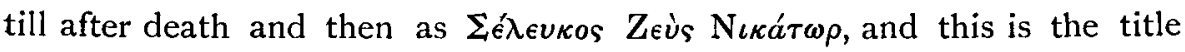
he officially bears in inscriptions. ${ }^{4}$

A decree of Ilion provides for a gold equestrian statue of Antiochus I.

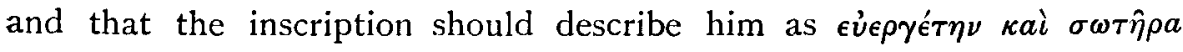

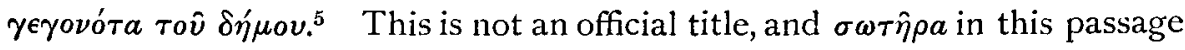
seems to have the sense of protector rather than saviour, and is not to be written with a capital sigma. Appian, a late and not very precise authority, says he won the title $\Sigma \omega \tau \eta^{\prime} \rho$ from having defeated the Gauls. ${ }^{6} \mathrm{He}$ may have been given the title after death for having defeated the Gauls during his lifetime. An inscription from Clazomenae decrees sacrifices to Antiochus, his wife Stratonike and his son Antiochus. ${ }^{7}$ On the other

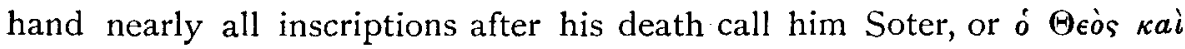
$\Sigma \omega \tau \grave{\eta} \rho$ 'A $\nu \tau i o \chi o s$, and he was officially deified as 'A $\Sigma \omega \tau \eta \dot{p} .{ }^{8}$ There are also in existence coins with the legend $\Sigma \Omega$ THPO $\Sigma$ ANTIOXOY ${ }^{9}$ with an elderly portrait of Antiochus; but it is very probable that these were struck after his death by his successor to commemorate his deification.

Appian ${ }^{10}$ again is our authority for saying that Antiochus II. was called $\Theta e$ és by the Milesians. He is not called so in inscriptions till after his:death." ${ }^{11}$ The Milesians may merely have given him honours as a god: in any case it was not a state official title.

Seleucus II. and Seleucus III. were not deified till after death. Likewise Antiochus III., his son Antiochus, and Seleucus IV., though they had

1 Dittenberger, O.G.I. 212.

3 Dittenberger, Syll. ${ }^{2}$ i. 250, $25^{1}$.

$$
2 \text { v. } 255 \text { a. }
$$

${ }^{4}$ Appian, Syr. 63 ; C.I.G. $445^{8}=$ Dittenberger O.G.I. 245 ; Dittenberger O.G.I. 233.

5 Dittenberger, O.G.I. 219.

${ }^{6}$ Syr. 65; Dittenberger dates the Bargylia inscription (Syll. ${ }^{2}$ i. 216) to Antiochus' lifetime merely because of this passage of Appian. The king's name is restored, and of the Soter the first half is wanting.

\footnotetext{
7 Dittenberger, O.G.I. 222.

9 B.M.Cat. Seleucids, PI. III. 7.

8 Id. ibid. 229, 233, 245, 246.

11 Dittenberger, O.G.I. 229, 233, 245, 246. 
priests while alive, did not become $\Theta \epsilon o$ i officially till after death. ${ }^{1}$ It is noticeable that the first Seleucid who officially called himself @eós while alive was Antiochus IV. It is quite likely that he only adopted this style after his successful invasion of Egypt, where the native priests, to judge by Ptolemaic precedents, almost certainly hailed him as @eós.

From this evidence it is clear that Kornemann's conclusions are correct, that none of the early Diadochi with the exception of the Ptolemies were deified till after death. The exception in the case of the Ptolemaic dynasty is due entirely to Egyptian religious ideas and customs. As regards the suggested theory that the official title $\Sigma \omega \tau \eta^{\prime} \rho$ always implies deification, there is at present no evidence against it, except the doubtful case of Antiochus I. ${ }^{2}$ In any case the name is given him only by a flattering city, and a distinction must always be drawn between the extravagant honours paid to monarchs by servile city-states, and between state titles officially adopted by rescripts or decrees. This, taken with the passage of Polybius, a contemporary author, is a very strong reason for believing that our hypothesis is correct. Kornemann ${ }^{3}$ says 'Die von Göttern entlehnten ehrenden Beinamen wie Soter (des Ptolemaios) oder Nikator (des Seleukos) haben aber bei Lebzeiten der Herrscher keine offizielle Geltung gehabt und beweisen gar nichts für staatlich eingesetzte Herrscherkulte für die ersten Diadochen bei ihren Lebzeiten.' Finally it is noticeable that of the other dynasties, Eumenes II. and Antiochus IV were the first to be deified while alive. The earliest date for Eumenes II. being so is I67, also after Antiochus IV's invasion of Egypt.

It is probable, then, that Antiochus first received divine honours in Egypt, and that having once become a god, he continued to call himself one in his own dominions; and that Eumenes II. not wishing to be unequal to his friend and neighbour ${ }^{4}$ followed his example and had himself deified as $\mathbf{E} \dot{u} \mu e^{\prime} \nu \eta \bar{\Sigma} \mathbf{\Sigma} \boldsymbol{\omega} \tau \dot{\eta} \rho$.

H. J. W. Tillyard.

Alan J. B. Wace.

${ }^{1}$ Dittenberger, O.G.I. 233, 245, 246. In the Magnesia inscription (233) Seleucus III. though

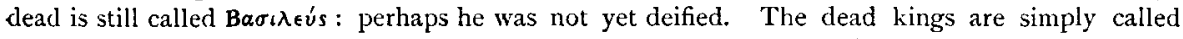

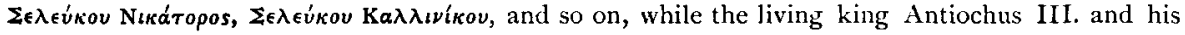
son have the title $B \alpha \sigma i \lambda \in u ́ s$.

${ }^{2}$ Cf. Niese, op. cit. ii. pp. 7 I, 8o. $\quad{ }^{3}$ op. cit. p. 67.

4 Close relations existed between them; Dittenberger, O.G. 1. 248. 